\title{
Respiratory medication used in COPD patients from seven Latin American countries: the LASSYC study [Corrigendum]
}

Casas A, Montes de Oca M, Menezes AMB, Wehrmeister FC, Lopez Varela MV, Mendoza L, Ramírez L, Miravitlles M. Int J Chron Obstruct Pulmon Dis. 2018;13:1545-1556.

Page 1552, Disclosure, the text "AM has been paid for her work as a statistician for the LASSYC study. LR is an employee of AstraZeneca. The other authors report no conflicts of interest in this work" should read "AMM has been paid by AstraZeneca and GlaxoSmithKline for her work as a statistician for the LASSYC and PLATINIO studies, respectively. LR is an employee of AstraZeneca. MM has received speaker fees from Boehringer Ingelheim, Chiesi, Cipla, Menarini, Rovi, Bial, CSL Behring, Grifols and Novartis; consultancy fees from Boehringer Ingelheim, Chiesi, GlaxoSmithKline, Bial, Gebro Pharma, CSL Behring, Laboratories Esteve, Mereo BioPharm, Verona Pharma, $\mathrm{pH}$ Pharma, Novartis and Grifols; and research grants from GlaxoSmithKline and Grifols. The authors report no other conflicts of interest in this work".
International Journal of COPD

\section{Publish your work in this journal}

The International Journal of COPD is an international, peer-reviewed journal of therapeutics and pharmacology focusing on concise rapid reporting of clinical studies and reviews in COPD. Special focus is given to the pathophysiological processes underlying the disease, intervention programs, patient focused education, and self management protocols.

\section{Dovepress}

This journal is indexed on PubMed Central, MedLine and CAS. The manuscript management system is completely online and includes a very quick and fair peer-review system, which is all easy to use. Visit http://www.dovepress.com/testimonials.php to read real quotes from published authors.

Submit your manuscript here: http://www.dovepress.com/international-journal-of-chronic-obstructive-pulmonary-disease-journal 